\title{
PERCEIVED FEATURES OF PRACTICUM EFFECTIVENESS AND ACQUIRED PROFESSIONAL COMPETENCES AMONG GRADUATE CLASS STUDENTS IN DILLA UNIVERSITY
}

\author{
Dinaol Urgessa, Sintayehu Abebe, Getachew Abeshu
}

\begin{abstract}
Навіть незважаючи на те, щзо практикум має інтегрувати та використовувати щьойно набуті теорії, навички та знання, існує величезна несумірність між типами навичок та знань, наданих освітніми програмами, та реаліями робочої практики.

Мета дослідження - вивчити наочні особливості ефективності практикуму та набутої професіональної компетентності студентів-випускників.

Методи: було використано кількісний дослідний підхід та описовий дизайн. Усі 169 студентивипускники університету Dilla були обрані за допомогою багатоступінчастої вибірки. Анкети було використано як засіб збору даних. Середнє, стандартне відхилення, особистісна кореляція та однобічний аналіз дисперсії було використано для аналізу даних.
\end{abstract}

Результат: Результат демонструе готовність до майбутньої роботи на рівні (М=2,0809, $S D=0,58024)$, творчий рiст $(M=1,7678, S D=0,61876)$, та рівень практики вивчених теорій $(M=2,1302$, $S D=0,42897)$ відповідно. Для випускників щчо набули професіональної компетентності: знання, навички та етика, отримані підчас професійного навчання, були $(M=2,0000, S D=0,48659), \quad(M=2,1550$, $S D=0,43300)$, та $(M=1,9172, S D=0,48428)$ відповідно. Далі аналіз особистісної кореляції продемонстрував щьо відчутні особливості ефективності практикуму та набутої професіональної компетентності корелюють помірно позитивно $r(169)=0,367, p<0,05$. Поряд з результатом, продемонстрованим однобічним дисперсійним аналізом, існує статистично значима різниця між рівнями студентського задоволення приймаючими організачіями практичної освіти, $(F(11,11)=3,477, p=0,025)$ - для студентівпсихологів та $(F(8,5)=5,747, p=0,035)$ - для студентів-журналістів.

Висновок: Практикум був та залитається менш ефективним для росту рівня студентської креативності та етики. То ж університети та приймаючі організації мають працювати заради покращенні студентської професіональної компетентності

Ключові слова: Практикум, відчутна ефективність практикуму, приймаюча організачія, професія, набута професіональна компетентність

Copyright (C) 2020, Dinaol Urgessa, Sintayehu Abebe, Getachew Abeshu. This is an open access article under the CC BY license (http://creativecommons.org/licenses/by/4.0).

\section{Introduction}

For most higher education students, field practicum is the first setting, in which they are able to integrate and apply acquired theories, values, skills, and knowledge under the supervision of course instructors [1] Practicum as a form of experiential edification exists to acquaint students with practical realities and processes while reinforcing the lessons, learned in the traditional classroom [2, 3]. Stated, that practicum is essential to the culmination of systematic learning in higher education, particularly in fields, such as health sciences and human services. A field placement is where students put into practice what they have learned in the classroom with respect to theories, skills and also with respect to upholding professional values and following ethical codes of conduct.

As students near graduation prepare for either their first professional positions or further education, almost all higher education institutions send their students to different institutions and organizations so as to provide opportunities to practice the theories, values, skills and knowledge they acquired from the classroom teaching and learning process in the actual practical manner.

\section{Literature review}

Practicum is a part of the students' academic training that constitutes an intermediate rung on the way to the beginning of their professional career [4]. According to [5], practicum also referred to as a field trip, have taken on an increasingly important role in education over the past decade since it presents students with many advantages, ranging from gaining experience and obtaining a career-related direction to networking with other students from various institutions as they are at the host organization, providing the placement. It also offers students the opportunity to review classroom knowledge, integrate this knowledge with the professional skills, required in the respective profession.

In this sense, practicum is the most important and relevant part of the teaching learning education program of higher institutions because it enables the students to develop some competences that can best be developed and extended during the practicum experience [6]. Practicum has a vital role in combining theoretical "learning" with hands- 
on "doing", provides opportunities for more permanent concept retention and behavioral change [2]. It also allows students to practice service provision in their respective areas, try out ideas, and have the confidence to make mistakes and to reflect and learn from them in order to develop new strategies. It is possible to hold an assumption that practicum prepares students for future work, practice of the students' previous learned concepts and enhance students' creativity [7]. As the study, conducted by [2], puts it, practicum experience exposes students to office politics and organizational structures, the wide variety of office standards and regional variability in the development code, and most importantly, a sense of independence.

Similarly, professional competence is an underlying aspect of practicum that implies overall psychology that includes motives, skills, abilities, selfimage, and knowledge [8]. In this case, practicum is one of the priority area, given due attention in the current teaching learning program of higher institutions.

In this regard, graduate students' perceived features of practicum effectiveness as psychological preparation have a golden share in creating the meaning to preservice education, glorifying academic wisdom and resilience in job quality service.

On the contrary to its importance, a widely discerned problem lies in the fact that there is often a huge disparity between the types of skills and knowledge, taught in pre-service programs, and the realities of workplace practice $[9,10]$. For instance, from their professional experience, they noticed that in one hand, the program is given a little attention by the institutions, concerning the program implementation, ranging from budget allocation, time allocation, students willingness and commitment to accomplish their task properly. On the other side, the host organizations may not allow and provide opportunities to students to carry out the task what they want to engaged on. However, facilities and service delivery system in the host organization that has a paramount role in promoting students' professional competence is an area of little attention.

As to the researchers' professional experience, besides the opportunities it offered to the students, we had a doubt that the current implementation of a practicum course is meeting its main aim and can bring significant values on students' learning among the Ethiopian universities. Thus, the researchers were initiated to conduct this study so as to explore, understand and describe the implementation of a practicum course in particular with reference to the perceived features of practicum effectiveness and acquired professional competencies' among graduate class students in Dilla University. To achieve these, the researcher sated the following three objectives.

\section{The aim and objectives of the study}

The aim of the study was to exploring perceived features of practicum effectiveness and acquired professional competences among graduate class students in Dilla University.

To achieve this aim, the following objectives were set:

1. determine the extent of student's satisfaction and acquired professional competence regarding practicum education;
2. assess whether is a relationship or not between perceived features of practicum effectiveness and acquired professional competence observed;

3. Examine whether there is a significant difference in the level of satisfaction with host organization services among various academic disciplines.

\section{Methods and materials}

The quantitative approach and descriptive design were employed. Students' perceived features of the practicum effectiveness and acquired professional competence were quantitatively examined. The study population was graduate class students of Dilla University, 2018/19 academic calendar. Total graduate class students of 2018/19 academic year were 2,500. The researchers employed a multistage sampling technique, where the study population was stratified, based on their college or institute. Colleges and institutes that had and had not a field trip or practicum were stratified. A non-proportional stratified sampling was used. Accordingly, departments that had a field trip or practicum program were identified. Finally, departments were selected using simple random sampling and the required sample size was also selected using the simple random sampling lottery method. From about 2,500 total regular program graduate students, 535 of them were the target population. Among the total target population, using inclusion-exclusion criteria, about 200 students, who were not present in the university during the data collection, students, who had not completed most appropriate courses, related to the practicum, and who were not eligible to be graduated due to different factors, were excluded from the study. Thus, of 335 students, who fitted inclusion criteria, using standard set forms by professional researchers, 169 students were selected using the simple random sampling technique. Accordingly, [11] suggested that at $95 \%$ confidence and 0.05 margin of error for population 300, 169 sample size is possible.

Questionnaires were used and administered physically to the participants to collect the required data. Some of the questionnaires were adapted from previous studies and others were prepared by the researchers after reviewing literatures on the problem. Contents of the questionnaires for students encompass general background questions, perceived features of practicum effectiveness and acquired professional competence. Likert scale that was ranged from "strongly disagree" to "strongly agree" was used in questions, which tested the degree of respondents' agreement with particular variables of the study. The pilot study was conducted to ensure the psychometric reliability of the adapted and constructed items. After the pilot study was conducted, at 0.791 items discrimination was done on few items with few problems and final administration of the questionnaire took place.

After the required data collected, the first preliminary check has been done, the quantitative data coded, classified, and entered in to the computer, Statistical Package for Social Science software version 21 was used to analyze the data. Right through the study 0.05 level of significance was used. The extent of student's perceived feature of practicum effectiveness and acquired professional competence was analyzed using descriptive statis-tics, mean and standard deviation. The degree of relationship between perceived features of practicum effectiveness and acquired profession- 
al competence was analyzed using Pearson correlation. Differences in satisfaction with host organization services provision among various academic discipline students were analyzed using ANOVA.

\section{Results}

Table 1 depicted that graduate student's perception about practicum or field trip was considered under three features, such as readiness for future work, enhancement of student's creativity and practice of the learned concept.

Thus, with regard to perceived features of practicum effectiveness: readiness for future work $(M=2.0809$, $S D=58024)$, enhancement of student's creativity $(M=1.7678, S D=0.61876)$, and practice of the learned concept $(M=2.1302, S D=0.42897)$.

Graduate students' perceived features of practicum effectiveness

\begin{tabular}{|c|c|c|c|c|}
\hline No. & Perceived features of practicum effectiveness & N & Mean Std. & Deviation \\
\hline 1 & Readiness for future work & 169 & 2.0809 & 0.58024 \\
\hline 2 & Enhancement of student's creativity & 169 & 1.7678 & 0.61876 \\
\hline 3 & Practice of the learned concept & 169 & 2.1302 & 0.42897 \\
\hline
\end{tabular}

Note: strongly disagree $=1.00-1.75$, Disagree $=1.76-2.5$, Agree $=2.51-3.25$ and strongly disagree $=3.26-4.00$

Table 2 depicted that graduate student's acquired professional competence was seen, based on students' knowledge, skills and ethics that students gained from the field trip. Hence, graduate students acquired knowledge $(M=2.0000, S D=0.48659)$, acquired skills $(M=2.1550$, $S D=0.43300)$, and $(M=1.9172, S D=0.48428)$.

As Table 3 indicated, perceived features of practicum effectiveness and acquired professional competence were moderately positively correlated $\mathrm{r} \quad(169)=0.367$, $\mathrm{p}<0.05$.

As showed in Table 4, demonstrated by one-way ANOVA, there was only a statistically significant difference between academic disciplines. Thus, Psychology and Journalism students had $(F(11.11)=3.477, p=0.025),(F(8.5)=$ $5.747, p=0.035)$ level of satisfaction with the service, rendered by host organizations, respectively.

Table 2

Acquired professional competence of graduate class students

\begin{tabular}{|c|c|c|c|c|}
\hline No. & Acquired professional competence & N & Mean Std. & Deviation \\
\hline 1 & Acquired knowledge & 169 & 2.0000 & 0.48659 \\
\hline 2 & Acquired skills & 169 & 2.1550 & 0.43300 \\
\hline 3 & Acquired ethics & 169 & 1.9172 & 0.48428 \\
\hline
\end{tabular}

Note: strongly disagree $=1.00-1.75$, Disagree $=1.76-2.5$, Agree $=2.51-3.25$ and strongly disagree $=3.26-4.00$

Table 3

Relationship between students perceived features of practicum effectiveness and acquired professional competence

\begin{tabular}{|c|c|c|c|}
\hline \multicolumn{2}{|c|}{ Behavior/measures } & $\begin{array}{l}\text { Perceived features of practicum } \\
\text { effectiveness }\end{array}$ & $\begin{array}{l}\text { Acquired professional } \\
\text { competence }\end{array}$ \\
\hline \multirow{3}{*}{$\begin{array}{c}\text { Perceived features of practicum } \\
\text { effectiveness }\end{array}$} & $\begin{array}{c}\text { Pearson } \\
\text { Correlation }\end{array}$ & 1 & $0.367^{* *}$ \\
\hline & Sig. (2-tailed) & & 0.000 \\
\hline & $\mathrm{N}$ & 169 & 169 \\
\hline \multirow{3}{*}{$\begin{array}{l}\text { Acquired professional } \\
\text { competence }\end{array}$} & $\begin{array}{c}\text { Pearson } \\
\text { Correlation }\end{array}$ & $0.367^{* *}$ & 1 \\
\hline & Sig. (2-tailed) & 0.000 & \\
\hline & $\mathrm{N}$ & 169 & 169 \\
\hline
\end{tabular}

Note: $* *$ - correlation is significant at the 0.01 level (2-tailed)

Table 4

Difference in student's satisfaction with services, rendered by host organizations

\begin{tabular}{|c|c|c|c|c|c|c|}
\hline \multicolumn{2}{|c|}{ Departments/category } & Sum of Squares & df & Mean Square & F & Sig. \\
\hline \multirow{3}{*}{ psychology } & 1 & 2 & 3 & 4 & 5 & 6 \\
\hline \multirow{3}{*}{ Economics } & Between Groups & 2.230 & 11 & 0.203 & 3.477 & 0.025 \\
\cline { 2 - 7 } & Within Groups & 0.641 & 11 & 0.058 & & \\
\cline { 2 - 7 } & Total & 2.871 & 22 & & & \\
\cline { 2 - 7 } & Between Groups & 0.943 & 7 & 0.135 & 0.397 & 0.858 \\
\cline { 2 - 8 } & Within Groups & 1.017 & 3 & 0.339 & & \\
\hline
\end{tabular}




\begin{tabular}{|c|c|c|c|c|c|c|}
\hline \multicolumn{7}{|c|}{ Continuation of Table 4} \\
\hline 1 & & 2 & 3 & 4 & 5 & 6 \\
\hline \multirow{3}{*}{ Journalism } & Between Groups & 1.253 & 8 & 0.157 & 5.747 & 0.035 \\
\hline & Within Groups & 0.136 & 5 & 0.027 & & \\
\hline & Total & 1.389 & 13 & & & \\
\hline \multirow{3}{*}{ Construction Management engineering } & Between Groups & 1.846 & 13 & 0.142 & 1.011 & 0.474 \\
\hline & Within Groups & 3.090 & 22 & 0.140 & & \\
\hline & Total & 4.936 & 35 & & & \\
\hline \multirow{3}{*}{ Mechanical engineering } & Between Groups & 1.256 & 14 & 0.090 & 0.957 & 0.520 \\
\hline & Within Groups & 2.251 & 24 & 0.094 & & \\
\hline & Total & 3.507 & 38 & & & \\
\hline \multirow{3}{*}{ Electrical engineering } & Between Groups & 2.707 & 14 & 0.193 & 1.333 & 0.250 \\
\hline & Within Groups & 4.060 & 28 & 0.145 & & \\
\hline & Total & 6.767 & 42 & & & \\
\hline
\end{tabular}

Note: $* *$ - significant at the 0.01 level (2-tailed)

\section{Discussion}

The discussion is introduced, based on the order of research objectives and major findings of the study.

Assessment of the student's state of perceived practicum effectiveness and acquired professional competence at Dilla University ( $N=169)$

As can be appeared in the finding section of the investigation, practicum adequacy is characterized with three domains: availability for future work, upgrades of students and students' practice of the learned concept were $\quad(M=2.0809, \quad \mathrm{SD}=58024), \quad(\mathrm{M}=1.7678$, $\mathrm{SD}=0.61876)$, and $(\mathrm{M}=2.1302, \mathrm{SD}=0.42897)$ separately. Graduate students obtained the professional competence; students' knowledge, skills and ethics, picked up from the field trip were $(\mathrm{M}=2.0000, \mathrm{SD}=0.48659)$, $(\mathrm{M}=2.1550, \quad \mathrm{SD}=0.43300), \quad$ and $\quad(\mathrm{M}=1.9172$, $\mathrm{SD}=0.48428$ ) individually.

There is a consistency between the present study and [4], suggested that the majority of graduate class students were very satisfied with the practicum experiences that they got. Similar study [6] found that the students' field trip apparently empowered them to build up certain capabilities that can best be created and reached out during the practicum experience.

Specifically concerning the student's extent of perception with respect to practicum effectiveness, the present study finding inferred that students had highest or significant perception that practicum or field trip will set them up for future work and disguise recently learned ideas, however more averse to upgrade their innovativeness. And furthermore, concerning graduate students' gained competency, the present investigation finding additionally implied students, believed that practicum profoundly improve their knowledge or insight and skills. Be that as it may, it is less likely to develop their ethics or morals.

The relationship of students perceived features of practicum effectiveness and acquired professional competence at Dilla University $(\mathrm{N}=169)$

The second objective of the present study was to test whether or not the two variables (students' perceived practicum effectiveness and their extent of acquired professional competence) were related or connected.

Accordingly, the present study finding discovered a fairly significant positive relationship between stu dents' perceived practicum effectiveness and professional competence $\mathrm{r}(169)=0.367, \mathrm{p}<0.05$. However, $[10,12]$ reported that there was an enormous difference between the two variables.

The present study implied that the higher the student's perception towards practicum effectiveness in enhancing their readiness for future work, creativity and practice learned ideas, the higher their professional competence in improving their knowledge, skills and ethics. The contradiction between the present investigation finding and the past one might be that graduate students of Dilla University may have the uplifting frame of mind to that of practicum effectiveness in making ready them for future work, inventiveness and practicing their inclined ideas. They might likewise have a higher level of initiation and commitment to be expertly competent than that of the past students, who partook in the previous study.

Differences in student's satisfaction with services, delivered by the host organization at Dilla University $(\mathrm{N}=169)$

The last aim of this study was to examine whether or not any significant difference in the level of satisfaction with host organization service delivery, related to the practicum course. Right now, the present study found that there was a significant difference in the level of satisfaction among students of different fields of study with services, delivered by the host organization. As showed up in the outcome segment, just Psychology and Journalism graduate students indicated a significant difference in their satisfaction with services, delivered by the host organization. There is no sufficient bodies of literature that show trainees' satisfaction with host organization service, however indirectly literature indicated that host has a contribution to the trainees' level of satisfaction. According to [4], the students value positively the practices in companies, especially for the learning that they acquire in the workplace. Another study [13] revealed host organizations on their commitment to continue supporting the internship program and the structure of benefits that students get from it [14]. Also suggested that the host organization environment has the most significant influence on internship satisfaction. As dictated in the study, conducted by [15], the participants of the study, who were enrolled in the practicum had been satisfied with the practicum course and host organization service. 


\section{Conclusions and recommendations}

Indisputably, the general findings, discovered in this study, are practically comparable to some other local and international studies that were conducted in different parts of Ethiopia and other developing countries' universities. Specifically, the result of this study repudiates different research findings. In particular, the result of this research contradicts to other studies findings. Consider- ing the practicum course in accordance with the universities/colleges' role, sending graduates at the start or end semester of their graduation year to the various associations is the piece of the higher organizations academic program. Thus, researchers suggested the Minister of Education, Universities and Host Organization to improve student's creativity and professional competence that can best enhance education quality.

\section{References}

1. I Found Myself at this Practicum: Student Reflections on Field Education / Williamson S., Hostetter C., Byers K., Huggins P. // Advances in Social Work. 2010. Vol. 11, Issue 2. P. 235-247. doi: http://doi.org/10.18060/346

2. Barbarash D. Knowledge and skill competency values of a university managed cooperative internship program: A case study in design education // Asia-Pacific Journal of Cooperative Education. 2016. Vol. 17, Issue 1. P. 21-30.

3. Chen R. K., Nguyen-Finn K. L., Park J. Effectiveness of Practicum Supervision as Perceived by Hispanic Undergraduate Rehabilitation Services Students // Journal of Applied Rehabilitation Counseling. 2018. Vol. 49, Issue 4. P 14-20. doi: http://doi.org/10.1891/0047-2220.49.4.14

4. Bartual-Figueras M. T., Purroy-Sanchez P., Turmo-Garuz J. Practicum and development of professional competences. The case of business students // EDULEARN19 Proceedings. 2019. doi: http://doi.org/10.21125/edulearn.2019.0768

5. Allen J. M., Wright S. E. Integrating theory and practice in the pre-service teacher education practicum // Teachers and Teaching: theory and practice. 2013. Vol. 20, Issue 2. P. 136-151. doi: http://doi.org/10.1080/13540602.2013.848568

6. Tuli F. Understanding Undergraduate Students Practicum Experience: A Qualitative Case Study Of Jimma University // Ethiopian Journal of Education and Sciences. 2010. Vol. 5, Issue 1. doi: http://doi.org/10.4314/ejesc.v5i1.56311

7. MoE. Teacher Education system Overhaul (TESO) document. Addis Ababa, 2003.

8. Guerrero D., De los Ríos I. Professional Competences: a Classification of International Models // Procedia - Social and Behavioral Sciences. 2012. Vol. 46. P. 1290-1296. doi: http://doi.org/10.1016/j.sbspro.2012.05.290

9. Meijer P. C., de Graaf G., Meirink J. Key experiences in student teachers' development // Teachers and Teaching: theory and practice. 2011. Vol. 17, Issue 1. P. 115-129. doi: http://doi.org/10.1080/13540602.2011.538502

10. Guerrero D., De los Ríos I. Professional Competences: a Classification of International Models // Procedia - Social and Behavioral Sciences. 2012. Vol. 46. P. 1290-1296. doi: http://doi.org/10.1016/j.sbspro.2012.05.290

11. Cohen L., Mansion L., Morrison K. Research methods in education. New York: Routledge, 2011.

12. Chen R. K., Nguyen-Finn K. L., Park J. Effectiveness of Practicum Supervision as Perceived by Hispanic Undergraduate Rehabilitation Services Students // Journal of Applied Rehabilitation Counseling. 2018. Vol. 49, Issue 4. P. 14-20. doi: http://doi.org/10.1891/0047-2220.49.4.14

13. Mgaya K., Mbekomize C. Benefits to host organizations from participating in internship programs in Botswana // AsiaPacific Journal of Cooperative Education. 2014. Vol. 15, Issue 2. P. 129-144.

14. Internship satisfaction: a preliminary study on undergraduates from the faculty of business and finance of Universiti Tunku Abdul Rahman / Jean C., Kawai H., Rong H., Chi O., Yi S. 2012. Available at: http://eprints.utar.edu.my/616/1/BA-20110905921.pdf

15. Aboomar R., AlJazi S., Alhasanat H. Evaluation of Teaching Practicum at the College of Educational Sciences from the Viewpoints of Student Teachers at Al-Hussein Bin Talal University (AHU) // Journal of Studies in Education. 2018. Vol. 8, Issue 2. P. 45. doi: http://doi.org/10.5296/jse.v8i2.12846

Getachew Abeshu, PhD, Department of Psychology, College of Education and Behavioral Science, Jimma University, P.O. Box 378, Jimma, Ethiopia

Dinaol Urgessa, Department of Psychology, College of Education and Behavioral Science, Jimma University P.O. Box 378, Jimma, Ethiopia

Sintayehu Abebe, Department of Psychology, College of Social Sciences and Humanity, Debre Berhan University 09 School of Computing, Debre Birhan, Ethiopia 